\title{
Impact of Land Use on Water Characteristics of Planosols (South Mačva and Pocerina, Serbia)
}

\author{
Mladen Dugonjić · Svjetlana Radmanović · Aleksandar Đorđević · \\ Zorica Tomić $\cdot$ Nataša Nikolić $\cdot$ Ljiljana Tanasić
}

\begin{abstract}
Summary: Water holding capacities and saturated hydraulic conductivity of Planosols in south Mačva and Pocerina (Serbia) were compared to assess how different types of land use (forest, arable and grassland) influence soils endangered by stagnating water. These changes came from decrease of total porosity and changes in pores size distribution in arable and grass land compared to forest land. Changes of water characteristics of arable and grassland Planosols compared to forest Planosols were statistically most significant in illuvial horizon Btg (absence of root network and fauna activity). It is important to emphasize: (i) surface A horizon of arable and grass land compared to forest showed insignificant increase of plant available water and significant decrease of saturated hydraulic conductivity (ii) significant decrease of saturation and macro porosity increased the risk of oxygen deficiency in Planosols in wet periods of year in this order: arable land $>$ grassland $>$ forest.

Keywords: arable land, forests, grasslands, Planosols, saturated hydraulic conductivity, water-holding capacity
\end{abstract}

\section{Introduction}

Planosols are soils with stagnating water and abrupt textural discontinuity (IUSS Working group WRB, 2014). According to Serbian soil classification (Skoric et al. 1985) this soil is designated Pseudogley. Planosols have an abrupt textural change within 100 $\mathrm{cm}$ of the soil surface and, directly above or below, a layer $5 \mathrm{~cm}$ or more thick, that has in some parts reducing conditions for some time during the year and in half or more of the soil volume, single or in combination and a stagnic colour pattern or an albic horizon, and no albeluvic tonguing starting within $100 \mathrm{~cm}$ of the soil surface (IUSS Working group WRB, 2014). Planosols are periodically wet in topsoil and subsoil caused by stagnating water. Water stagnates due to low hydraulic conductivity in clayey dense subsoil horizon. The agricultural suitability of Planosols is limited due to their oxygen deficiency resulting from stagnating water (IUSS Working group WRB, 2014).

Primary vegetation of Planosols in south Mačva and Pocerina was forest. Forest was succeeded by grassland and eventually the most of Planosols were

M. Dugonjić · Lj. Tanasić

Agricultural College of Vocational Studies, Vojvode Putnika 56, 15000 Šabac, Serbia

S. Radmanović* · A. Đorđević · Z. Tomić · N. Nikolić

University of Belgrade, Faculty of Agriculture, Nemanjina 6, 11080 Belgrade-Zemun, Serbia

e-mail: scupac@agrif.bg.ac.rs turned into arable land (Tanasijevic \& Pavicevic 1953, Tanasijevic et al. 1966). Forest vegetation was Quercetum frainetto-cerris, Rud. Small area of grassland was used in the same way for a long time, and the greater part of grassland was actually arable land that was abandoned recently (10-15 years ago). Arable land was used for growing cereals (wheat, maize, barley, oats), with generally low yields. Type of land use and agricultural management practices affect soil quality because they may cause alterations in soil physical and chemical properties and in soil biotic community (Caravaca et al. 2002) determining, in turn, a reduction in land productivity (Sanchez-Maranon et al. 2002, Marzaioli et al. 2010). Land use is a key parameter in the hydrologic cycle (soil hydrology), attributed to the effects of tillage, erosion, compaction, and pore structure evolution (Harden 2006, Rasiah et al. 1995). A full understanding of hydrologic response to human impact requires assessment of land-use impacts on key soil physical properties such as saturated hydraulic conductivity, bulk density, and moisture retention (Price et al. 2010).

Planosols have adverse water characteristics caused by dense illuvial subsoil horizon. Changes in land use cause the greatest change of surface layer. The aim of this paper was to determine the influence of conversion of Pseudogley under forest to arable and grass land, by way of measuring soil water characteristics. 


\section{Materials and Methods}

Planosols of southern Mačva and Pocerina cover about 18,000 ha (Dugonjić et al. 2013). Average temperatures of these two regions are similar: $11.2^{\circ} \mathrm{C}$ in southern Mačva (Šabac) and $11.3^{\circ} \mathrm{C}$ in Pocerina (Loznica). Average annual precipitation is lower in Šabac $(693.3 \mathrm{~mm})$ than in Loznica $(851.1 \mathrm{~mm})$. Water regime of Planosols is influenced by uneven precipitation during some years, and alteration of dry and wet years. Flat terrain of south Mačva and gently undulating relief of Pocerina slow the runoff of water from atmospheric deposits. All precipitation infiltrates into the soil and water stagnates in wetter periods of year above the Btg horizon.
Water characteristics of 9 soil profiles (3 of each type of land use: forest, grass and arable) of Planosols were determined (Figure 1). Co-ordinates and altitudes of soil

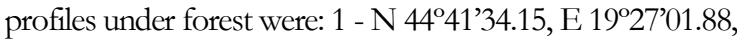
$89 \mathrm{~m}$ asl, 3 - N 44 43’59.64, E $19^{\circ} 35^{\circ} 05.45,84 \mathrm{~m}$ asl, and 9

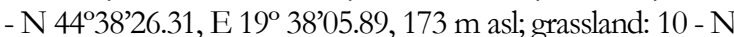

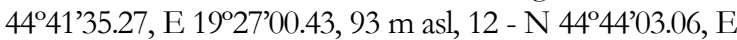
$19^{\circ} 35^{\prime} 03.68,76 \mathrm{~m}$ asl, and $18-\mathrm{N} 44^{\circ} 38^{\prime} 37.83$, E 19³7'58.90, 132 m asl; arable land: 19 - N 4441’35.03, E

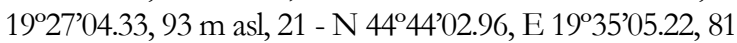
$\mathrm{m}$ asl., and $27-\mathrm{N} 44^{\circ} 38^{\prime} 35.98, \mathrm{E} 19^{\circ} 38^{\prime} 01.25,155 \mathrm{~m}$ asl. Examined Planosols have A-Eg-Btg-BtC-C profile. Figure 2 shows depth of soil horizons and textural differentiation within soil profile.

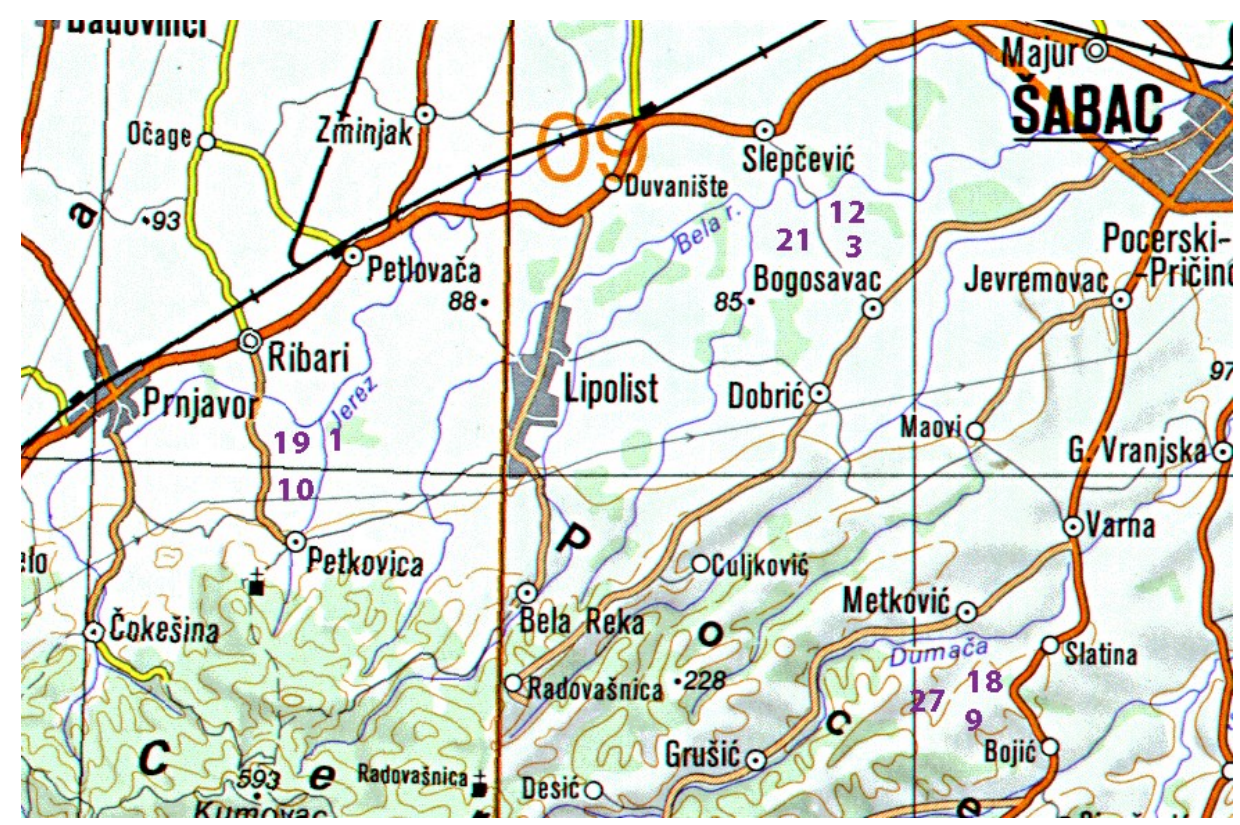

Figure 1. Study area with soil profiles under forest $(1,3,9)$, grassland $(10,12,18)$, and arable land $(19,21,27)$

Water characteristics for A, Eg and Btg horizon of Planosols were determined. Undisturbed (using 100 $\mathrm{cm} 3$ cylinders) and disturbed soil samples were taken in June 2006. From A, Eg and Btg horizons 5, 3 and 3 undisturbed soil samples were collected, respectively. Three soil moisture states, saturation, field capacity and permanent wilting point are used to describe water content across different water potentials in soil (O'Geen 2012). Saturation (S) represents soil water content when all soil pores are filled with water. Field capacity (FC) represents soil water content in the soil after having been wetted and after free drainage has ceased, i.e. soil water content retained against the force of gravity by matrix forces (in micro pores and meso pores) at tension of $-0.033 \mathrm{MPa}$. Lento-capillary point (LCP) is the point above which water is readily available to plants, and constitutes the main supply of water for plants under irrigated conditions. The point at which matrix forces hold water too tightly for plant extraction $(-1.5 \mathrm{MPa})$ is termed the permanent wilting point (PWP). The quantity of water held between field capacity and permanent wilting point is considered plant available water (PAW). In laboratory water holding capacities were determined on soil samples that have been equilibrated with water at various suction (tension) values: $-0.033,-0.625$ and $-1.5 \mathrm{MPa}$, using 15 Bar Ceramic Pressure Plate Extractor. The bulk density was calculated from the core sample weight (van Reeuwijk 2002). Soil saturation was calculated from the saturated core sample weight. Soil particle density was determined on disturbed soil samples using Albert-Bogs method. Total porosity was calculated: total porosity $(\%)=(1$-bulk density $/$ particle density)x100; pore size distribution $(>10 \mu \mathrm{m}$, $10-0.2 \mu \mathrm{m},<0.2 \mu \mathrm{m})$ by extracting water out of bulk soil samples, at -0.033 and $-1.5 \mathrm{MPa}$. Saturated hydraulic conductivity (SHC) was determined by falling head method.

Statistical data processing included descriptive statistics, correlation analysis and t-test (difference among 3 land-use types), using StatSoft, Inc. STATISTICA for Windows, version 8. 


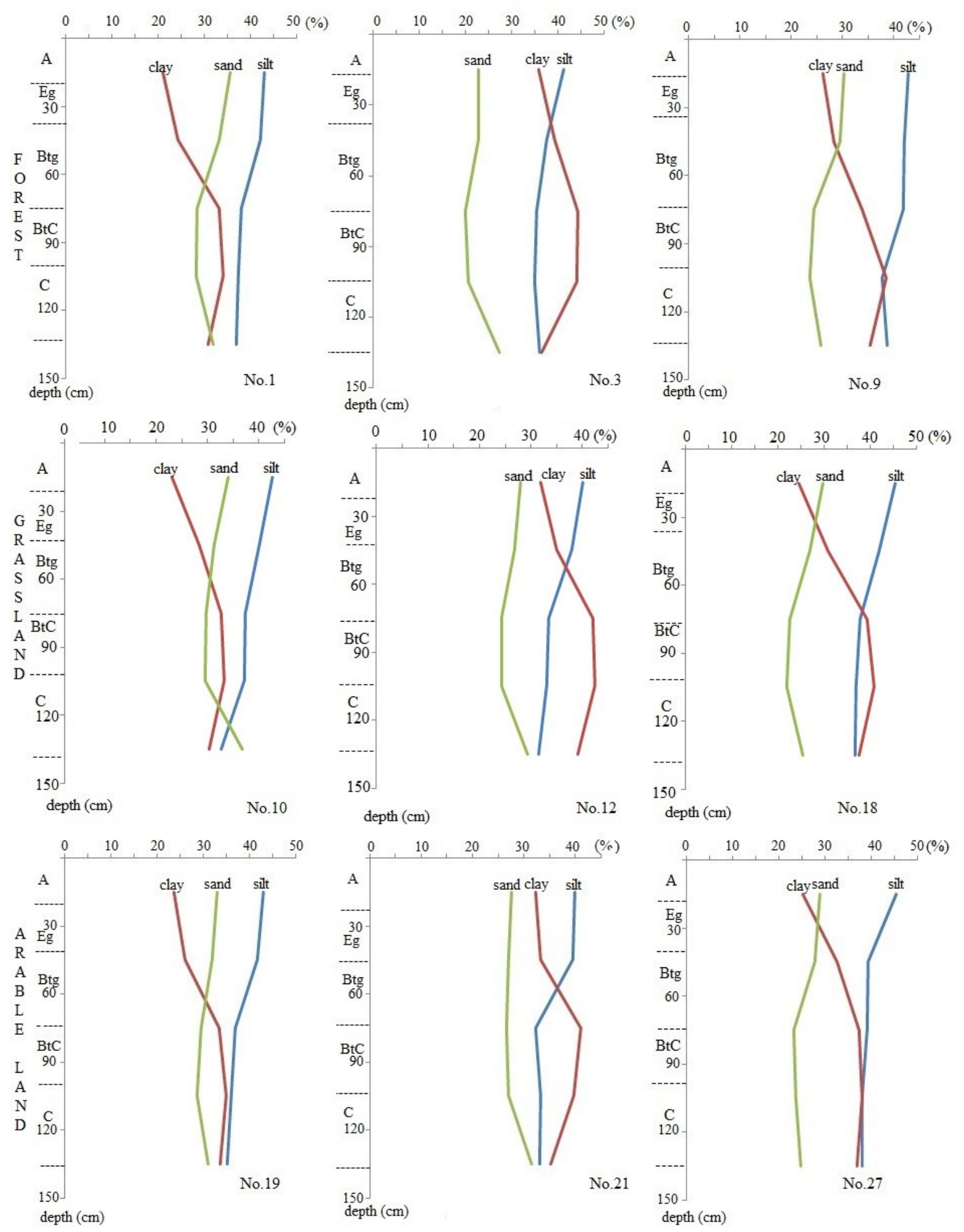

Figure 2. Vertical textural differentiations of Planosols under various types of use 


\section{Results and Discussion}

Table 1 shows soil texture and humus content of $\mathrm{A}, \mathrm{Eg}$ and Btg horizons of Planosols. Content of sand, silt and humus decreased and the content of clay increased with depth in all soil profiles. There is no significant difference in particle size distribution of forest, grassland and arable soil profiles of Planosols (results of t-test are not shown). Statistically significant was difference in humus content in Planosols under forest compared to Planosols under grassland $(\mathrm{t}=3.8212, \mathrm{p}=0.0051)$, and arable land $(\mathrm{t}=3.2459, \mathrm{p}=0.0118)$, while difference between Planosols under grass and arable land was not statistically significant.

Table 2 shows decrease of the average total porosity and macro pores with depth, from A, along Eg to Btg horizon, while, at the same time, content of micro pores increased, in all three different types of land-use. Figure 3 shows high levels of PWP and low levels of PAW in all types of Planosols, and all soil horizons. Figure 4 shows Planosols moderate to very slow saturated hydraulic conductivity, which decreased with depth in all soil profiles. Eg horizon had significantly slower hydraulic conductivity compared to A horizon $(t=-3.55426, p=0.016314)$.

Planosols under grass and arable land compared to those under forest (Table 3) had significantly lower total porosity and macro pores content and also $\mathrm{S}$ values. Content of micro pores and FC, LCP and PWP values were significantly higher. PAW was also higher, but not statistically significant. On arable land hydraulic conductivity was lower $(p<0.05)$. Difference in porosity and water characteristics between grass and arable land, through the whole soil profile, was small and statistically insignificant.

Differences between grassland and forest land (Table 4), and also between arable land and forest land, are the most visible in Btg horizon, then in A, and the least in Eg horizon. In A horizon difference between grass land and forest land, and difference between arable land and forest are of the same sign. In grass land, there is a reduction of meso pores content and PAW in Btg, and in arable land in $\mathrm{Eg}$ horizon. Differences between arable land and grass land were the greatest in A horizon, and they lessened with depth.

Correlation analysis (Table 5) showed that $\mathrm{S}$ was highly positively correlated with humus content, total porosity and macro pores content, and negatively correlated with micro pore content and clay content. FC and LCP were positively correlated with meso pores and micro pores, and negatively correlated with total porosity and macro pores. PWP was positively correlated with clay, and negatively correlated with total porosity and macro pores. Our results of correlation analysis for S, FC, LCP and PWP are compliant to published data (Hillal 1971). PAW and SHC did not show significant correlation with either of the investigated parameters.

Table 1. Soil texture and humus content of A, Eg and Btg horizons of Planosols under different types of land use (mean \pm std.dev.)

\begin{tabular}{|c|c|c|c|c|c|}
\hline \multirow{3}{*}{ Land use } & \multirow[b]{2}{*}{ Horizon } & \multirow{2}{*}{$\begin{array}{c}\text { Sand } \\
2-0.2 \mathrm{~mm}\end{array}$} & \multirow{2}{*}{$\begin{array}{c}\text { Silt } \\
0.02-0.002 \mathrm{~mm}\end{array}$} & \multirow{2}{*}{$\begin{array}{c}\text { Clay } \\
<0.002 \mathrm{~mm}\end{array}$} & \multirow{2}{*}{ Humus } \\
\hline & & & & & \\
\hline & & $\%$ & $\%$ & $\%$ & $\%$ \\
\hline \multirow{4}{*}{ Forest } & A & $29.66 \pm 6.47$ & $42.37 \pm 0.95$ & $27.77 \pm 7.42$ & $3.35 \pm 0.49$ \\
\hline & $\mathrm{Eg}$ & $28.53 \pm 5.30$ & $40.68 \pm 2.55$ & $30.79 \pm 7.78$ & $1.58 \pm 0.23$ \\
\hline & Btg & $24.32 \pm 4.25$ & $38.54 \pm 3.21$ & $37.15 \pm 6.33$ & $0.94 \pm 0.04$ \\
\hline & total & $27.50 \pm 5.29$ & $40.53 \pm 2.68$ & $31.90 \pm 7.49$ & $1.96 \pm 1.12$ \\
\hline \multirow{4}{*}{$\begin{array}{l}\text { Grass } \\
\text { land }\end{array}$} & A & $29.90 \pm 2.82$ & $42.95 \pm 2.78$ & $27.15 \pm 4.57$ & $2.03 \pm 0.18$ \\
\hline & $\mathrm{Eg}$ & $28.96 \pm 2.70$ & $40.29 \pm 1.23$ & $30.75 \pm 3.91$ & $0.94 \pm 0.10$ \\
\hline & Btg & $26.50 \pm 3.13$ & $36.18 \pm 3.55$ & $37.32 \pm 3.80$ & $0.78 \pm 0.13$ \\
\hline & total & $28.45 \pm 2.93$ & $39.81 \pm 3.76$ & $31.74 \pm 5.71$ & $1.25 \pm 0.60$ \\
\hline \multirow{4}{*}{$\begin{array}{l}\text { Arable } \\
\text { land }\end{array}$} & $\mathrm{A}$ & $29.90 \pm 2.82$ & $42.95 \pm 2.78$ & $27.15 \pm 4.57$ & $1.93 \pm 0.16$ \\
\hline & $\mathrm{Eg}$ & $28.96 \pm 2.70$ & $40.29 \pm 1.23$ & $30.75 \pm 3.91$ & $0.98 \pm 0.14$ \\
\hline & Btg & $26.50 \pm 3.13$ & $36.18 \pm 3.55$ & $37.32 \pm 3.80$ & $0.88 \pm 0.10$ \\
\hline & total & $28.45 \pm 2.93$ & $39.81 \pm 3.76$ & $31.74 \pm 5.71$ & $1.26 \pm 0.51$ \\
\hline
\end{tabular}


Table 2. Total porosity and pore size distribution in A, Eg and Btg horizons of Planosols under different types of land use (mean \pm std.dev.)

\begin{tabular}{|c|c|c|c|c|c|}
\hline \multirow[t]{2}{*}{ Land use } & \multirow[t]{2}{*}{ Horizon } & $\begin{array}{c}\text { Total } \\
\text { porosity }\end{array}$ & macro $>10$ & $\begin{array}{l}\text { Pores }(\mu \mathrm{m}) \\
\text { meso } 10-0.2\end{array}$ & micro $<0.2$ \\
\hline & & \multicolumn{4}{|c|}{$\%$ vol. } \\
\hline \multirow{4}{*}{ Forest } & A & $50.5 \pm 3.6$ & $15.9 \pm 5.5$ & $17.6 \pm 1.2$ & $17.0 \pm 0.8$ \\
\hline & $\mathrm{Eg}$ & $44.4 \pm 2.3$ & $10.0 \pm 3.5$ & $17.6 \pm 1.3$ & $16.8 \pm 0.6$ \\
\hline & Btg & $41.8 \pm 0.2$ & $5.5 \pm 1.5$ & $18.3 \pm 0.7$ & $18.0 \pm 0.6$ \\
\hline & total & $45.5 \pm 4.4$ & $10.4 \pm 5.6$ & $17.8 \pm 1.0$ & $17.3 \pm 0.8$ \\
\hline \multirow{4}{*}{$\begin{array}{l}\text { Grass } \\
\text { land }\end{array}$} & $\mathrm{A}$ & $45.0 \pm 2.0$ & $8.5 \pm 2.8$ & $18.7 \pm 0.4$ & $17.7 \pm 0.6$ \\
\hline & $\mathrm{Eg}$ & $40.0 \pm 0.7$ & $4.8 \pm 1.3$ & $18.0 \pm 0.3$ & $17.5 \pm 1.0$ \\
\hline & Btg & $39.2 \pm 0.2$ & $1.6 \pm 0.9$ & $18.1 \pm 0.6$ & $19.4 \pm 0.4$ \\
\hline & total & $41.4 \pm 2.9$ & $4.9 \pm 3.4$ & $18.3 \pm 0.5$ & $18.2 \pm 1.1$ \\
\hline \multirow{4}{*}{$\begin{array}{l}\text { Arable } \\
\text { land }\end{array}$} & A & $43.6 \pm 1.8$ & $7.7 \pm 2.6$ & $18.3 \pm 0.6$ & $17.6 \pm 0.6$ \\
\hline & $\mathrm{Eg}$ & $40.6 \pm 0.8$ & $4.9 \pm 2.2$ & $17.6 \pm 1.4$ & $18.1 \pm 1.0$ \\
\hline & Btg & $39.0 \pm 0.8$ & $1.7 \pm 1.1$ & $17.7 \pm 0.6$ & $19.6 \pm 0.3$ \\
\hline & total & $41.1 \pm 2.3$ & $4.8 \pm 3.2$ & $17.8 \pm 0.9$ & $18.4 \pm 1.1$ \\
\hline
\end{tabular}
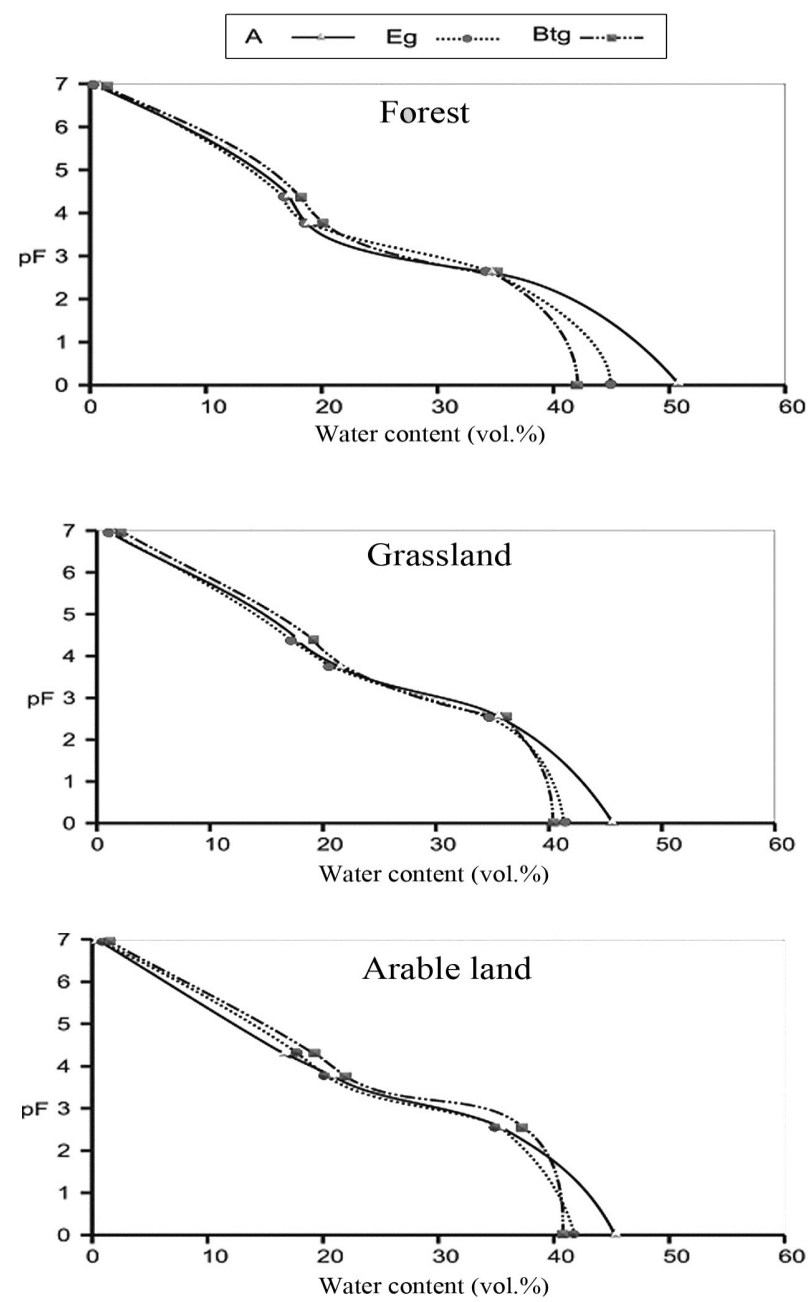

Figure 3. pF curve of Planosols (south Mačva and Pocerina, Serbia) for different types of use and genetic horizons 


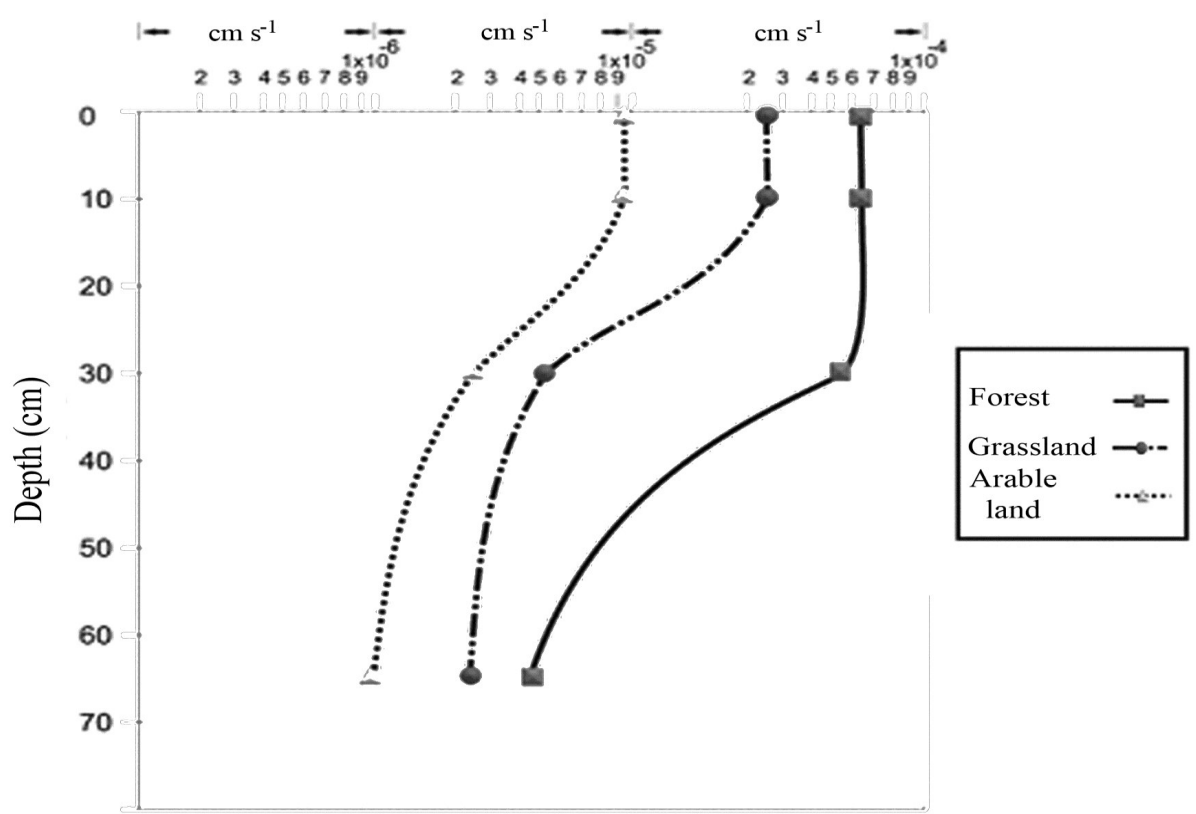

Figure 4. Saturated hydraulic conductivity of Planosols (south Mačva and Pocerina, Serbia) for different types of use and genetic horizons

Table 3. Statistically significant difference in soil porosity and water characteristics of Planosols under different types of land use $\left({ }^{*} \mathrm{p}<0.05 ;{ }^{* *} \mathrm{p}<0.01\right)$

\begin{tabular}{lcccccc}
\hline Parameter & \multicolumn{2}{c}{ Grassland : Forest } & \multicolumn{2}{c}{ Arable Land : Forest } & \multicolumn{2}{c}{ Arable Land : Grassland } \\
\cline { 2 - 7 } & $\mathrm{t}$ & $\mathrm{p}$ & $\mathrm{t}$ & $\mathrm{p}$ & $\mathrm{t}$ & $\mathrm{p}$ \\
\hline total porosity & $-5.8274^{* *}$ & $0.0004^{* *}$ & $-5.0807^{* *}$ & $0.0009^{* *}$ & -1.0059 & 0.3439 \\
macrop. $>10 \mu \mathrm{m}$ & $-6.0515^{* *}$ & $0.0003^{* *}$ & $-6.2832^{* *}$ & $0.0002^{* *}$ & -0.2090 & 0.8396 \\
mesop.10-0.2 $\mu \mathrm{m}$ & 1.4720 & 0.1792 & 0.1014 & 0.9217 & -1.9127 & 0.0921 \\
microp. $<0.2 \mu \mathrm{m}$ & $5.5308^{* *}$ & $0.0005^{* *}$ & $4.9091^{* *}$ & $0.0012^{* *}$ & 1.0439 & 0.3270 \\
$\mathrm{~S}$ & $-5.7266^{* *}$ & $0.0004^{* *}$ & $-4.9074^{* *}$ & $0.0012^{* *}$ & -0.3605 & 0.7278 \\
FC & $4.2965^{* *}$ & $0.0026^{* *}$ & $3.8539^{* *}$ & $0.0048^{* *}$ & -0.8538 & 0.4180 \\
LCP & $4.8433^{* *}$ & $0.0012^{* *}$ & $9.1431^{* *}$ & $0.0000^{* *}$ & -0.7327 & 0.4846 \\
PWP & $5.5308^{* *}$ & $0.0005^{* *}$ & $4.7964^{* *}$ & $0.0013^{* *}$ & 0.9585 & 0.3659 \\
PAW & 1.4720 & 0.1792 & 0.1014 & 0.9217 & -1.9127 & 0.0921 \\
SHC & 0.8353 & 0.4278 & $-2.6196^{*}$ & $0.0307^{*}$ & -1.0641 & 0.3183 \\
\hline
\end{tabular}

S-saturation; FC-field capacity; LCP - lento capillary point, PWP-permanent wilting point; PAW-plant available water; SHC-saturated hydraulic conductivity

Results showed that different types of land use of Planosols from Mačva and Pocerina caused statistically significant difference of soil porosity and the most of soil water-holding capacities. According to Marzaioli et al. (2010) when soils are classified as the same type and show similar soil texture, any differences in soil quality could be attributed to different land use. Price et al. (2010) say that if particle size distribution does not significantly differ among land-use classes or parent materials, than the differences between the hydraulic properties of forest vs. non-forest soils were attributed to compaction associated with land management practices. As there is no significant difference in particle size distribution of forest, grassland and arable Planosols examined in this paper, nor in other examined Planosols in Mačva and Pocerina, as reported by Dugonjic et al. (2011), it could be concluded that different water characteristics come from different types of land use. Transition of forest to arable land and grass land took place a long time ago (there are no records of it), and the differences between forest Planosol against grassland and arable land Planosol for the most parameters were statistically significant. Most of the grasslands are abandoned (in last $10-15$ years) arable land. This caused differences between arable and grass land to be minor and statistically insignificant. 
Table 4. Statistically significant difference in soil porosity and water characteristics of Planosols, by horizons $(* \mathrm{p}<0.05$; $* * \mathrm{p}<0.01)$

\begin{tabular}{|c|c|c|c|c|c|c|}
\hline \multirow[t]{2}{*}{ Parameter } & \multicolumn{2}{|c|}{ Grassland : Forest } & \multicolumn{2}{|c|}{ Arable Land : Forest } & \multicolumn{2}{|c|}{ Arable Land : Grassland } \\
\hline & $\mathrm{t}$ & $\mathrm{p}$ & $\mathrm{t}$ & $\mathrm{p}$ & $\mathrm{t}$ & $\mathrm{p}$ \\
\hline \multicolumn{7}{|l|}{ A horizon } \\
\hline total porosity & $-5.3670 *$ & $0.0331 *$ & $-5.881 *$ & $0.0277^{*}$ & $-8.9578^{*}$ & $0.0122^{*}$ \\
\hline macrop. $>10 \mu \mathrm{m}$ & $-4.5422 *$ & $0.0452 *$ & $-4.801 *$ & $0.0407^{*}$ & $-4.6320 *$ & $0.0436^{*}$ \\
\hline mesop. $10-0.2 \mu \mathrm{m}$ & 2.2956 & 0.1486 & 2.0532 & 0.1764 & -2.7525 & 0.1105 \\
\hline microp. $<0.2 \mu \mathrm{m}$ & 3.4868 & 0.0733 & 2.4615 & 0.1329 & -0.5170 & 0.6566 \\
\hline S & $-6.9686^{*}$ & $0.0200^{*}$ & $-8.265^{*}$ & $0.0143^{*}$ & $-10.435^{* *}$ & $0.0091 * *$ \\
\hline $\mathrm{FC}$ & 3.1134 & 0.0895 & 2.2364 & 0.1548 & -2.8099 & 0.1067 \\
\hline LCP & 3.2862 & 0.0814 & $6.3214^{*}$ & $0.0241 *$ & -1.6083 & 0.2490 \\
\hline PWP & 3.4868 & 0.0733 & 2.3132 & 0.1468 & -0.5806 & 0.6202 \\
\hline PAW & 2.2956 & 0.1486 & 2.0532 & 0.1765 & -2.7525 & 0.1105 \\
\hline SHC & -1.8833 & 0.2004 & -1.9607 & 0.1890 & -0.9019 & 0.4623 \\
\hline \multicolumn{7}{|l|}{ Eg horizon } \\
\hline total porosity & -2.5549 & 0.1251 & -2.1209 & 0.1680 & 2.5040 & 0.1293 \\
\hline macrop. $>10 \mu \mathrm{m}$ & -2.6441 & 0.1182 & -3.8361 & 0.0617 & 0.5223 & 0.6536 \\
\hline mesop. $10-0.2 \mu \mathrm{m}$ & 0.6838 & 0.5647 & -0.0256 & 0.9819 & -0.5747 & 0.6235 \\
\hline microp. $<0.2 \mu \mathrm{m}$ & 2.4263 & 0.1360 & $6.4224^{*}$ & $0.0234^{*}$ & 2.1360 & 0.1662 \\
\hline S & -2.3196 & 0.1462 & -2.2878 & 0.1494 & 1.7588 & 0.2207 \\
\hline $\mathrm{FC}$ & 2.5120 & 0.1286 & 2.5579 & 0.1248 & -2.5579 & 0.1249 \\
\hline LCP & 3.5104 & 0.0724 & 3.7212 & 0.0652 & -0.1055 & 0.9256 \\
\hline PWP & 2.4263 & 0.1360 & $6.4224^{*}$ & $0.0234^{*}$ & 2.1360 & 0.1662 \\
\hline PAW & 0.6838 & 0.5647 & -0.0256 & 0.9819 & -0.5747 & 0.6235 \\
\hline $\mathrm{SHC}$ & -2.9396 & 0.0989 & -3.1994 & 0.0854 & -1.8507 & 0.2054 \\
\hline \multicolumn{7}{|l|}{ Btg horizon } \\
\hline total porosity & $-12.756^{* *}$ & $0.0061 * *$ & $-6.630^{*}$ & $0.0220^{*}$ & -0.4009 & 0.7272 \\
\hline macrop. $>10 \mu \mathrm{m}$ & $-6.3631 *$ & $0.0238^{*}$ & $-9.420^{*}$ & $0.0111^{*}$ & 0.5400 & 0.6435 \\
\hline mesop.10-0.2 $\mu \mathrm{m}$ & -0.4472 & 0.6985 & $-6.104^{*}$ & $0.0258^{*}$ & -1.5437 & 0.2626 \\
\hline microp. $<0.2 \mu \mathrm{m}$ & $8.1625^{*}$ & $0.0147^{*}$ & 3.2806 & 0.0817 & 0.4893 & 0.6730 \\
\hline S & -3.7753 & 0.0635 & -2.8974 & 0.1013 & 3.1322 & 0.0886 \\
\hline $\mathrm{FC}$ & 1.6681 & 0.2372 & 1.3504 & 0.3094 & -0.8932 & 0.4660 \\
\hline LCP & 1.7523 & 0.2218 & 5.4738 & $0.0318^{*}$ & 0.1219 & 0.9141 \\
\hline PWP & $8.1625^{*}$ & $0.0147^{*}$ & 3.2806 & 0.0817 & 0.4893 & 0.6730 \\
\hline PAW & -0.4472 & 0.6985 & -6.1041 & $0.0258^{*}$ & -1.5437 & 0.2626 \\
\hline SHC & -2.0375 & 0.1785 & -2.0744 & 0.1738 & -2.1387 & 0.1659 \\
\hline
\end{tabular}

S-saturation; FC-field capacity; LCP -lento capillary point ; PWP - permanent wilting point; PAW- plant available water; SHC-saturated hydraulic conductivity 
Table 5. Correlation between soil water characteristics and soil porosity, clay and humus content $(* \mathrm{p}<0.05 ; * * \mathrm{p}<0.01)$

\begin{tabular}{|c|c|c|c|c|c|c|}
\hline \multirow[t]{2}{*}{$\mathrm{r}$} & \multirow{2}{*}{ Total porosity } & \multicolumn{3}{|c|}{ Pores $(\mu \mathrm{m})$} & \multirow{2}{*}{ Clay } & \multirow{2}{*}{ Humus } \\
\hline & & $>10$ & $10-0.2$ & $<0.2$ & & \\
\hline$S$ & $0.99 * *$ & $0.95^{* *}$ & -0.17 & $-0.65^{* *}$ & $-0.52^{* *}$ & $0.83^{* *}$ \\
\hline FC & $-0.53^{* *}$ & $-0.75^{* *}$ & $0.78^{* *}$ & $0.87 * *$ & 0.48 & -0.25 \\
\hline LCP & $-0.59 * *$ & $-0.78^{* *}$ & $0.75^{* *}$ & $0.82 * *$ & 0.48 & -0.32 \\
\hline PWP & $-0.64 * *$ & $-0.80^{* *}$ & 0.39 & 1.00 & $0.50 * *$ & -0.43 \\
\hline PAW & -0.17 & -0.40 & 1.00 & 0.39 & 0.26 & 0.10 \\
\hline SHC & 0.13 & 0.05 & 0.23 & 0.02 & -0.32 & 0.25 \\
\hline
\end{tabular}

S - saturation; FC- field capacity; LCP - lento capillary point; PWP - permanent wilting point; PAW- plant available water; SHC- saturated hydraulic conductivity

Our results comply with literature data. Lee and Foster (1991) state that, compared to soils with human impact (different land use), soils under native vegetation (e.g. undisturbed forest) generally feature low bulk density and high saturated hydraulic conductivity, total porosity, and macro porosity, as a result of ample litter cover, organic inputs, root growth and decay, and abundant burrowing fauna. In contrast, soils exposed to human impact are often stripped of organic-rich upper horizons and compacted by heavy equipment or livestock. Replacement of natural vegetation by managed land cover is generally associated with decreased rooting networks and faunal activity, thereby reducing the potential for well-developed macro pore networks and increasing bulk density. The reduced macro porosity is the main reason for lower permeability (reduction of saturated hydraulic conductivity as well as infiltration rate) of the surface of agricultural land compared to natural (Giertz et al. 2005, Reiners et al. 1994, Schwartz et al. 2003).

Content of PAW was slightly higher in grass and arable land compared to forest land. According to Giertz et al. (2005) continuous measurement of soil moisture show that agricultural fields have higher soil moisture compared to forest, due to reduction of evapotranspiration and soil water withdrawal. The greatest difference of arable and grassland opposite to forest land was in illuvial Btg horizon, then in A horizon, and the least in Eg horizon, for the most water parameters. Rooting network of forest species is deep and penetrates Btg horizon (deeper than 33 $\mathrm{cm}$ ). In grassland and arable land root is shallow. It is well established in A horizon, somewhat lesser in Eg horizon and in most cases it does not penetrate Btg horizon. This has the most important impact on significant differences of total porosity and pore size distribution, the greatest decrease of macro pores and the increase of micro pores, which caused increase in PWP values. Previous findings are supported by the fact that the greatest difference between arable land and grass land were in A horizon, and it lessened toward Btg, where rooting network is absent. The rooting systems of woody vegetation such as forest and shrub land demonstrate substantially greater depth, diameter, dispersion, and biomass than rooting systems of herbaceous plants or cultivated crops (Price et al. 2010).

Differences between arable and grassland opposite to forest land were the least in Eg horizon because this horizon had distorted structure, thus the change in land use had the minor impact on total porosity and pores size distribution, and consequently changes in water characteristics of this horizon. Eg horizon of arable land, opposite to forest land, had significant increase of micro porosity, thus increasing PWP values. This difference was present between arable and grass land but was statistically insignificant. This could be caused by soil compaction of subsurface Eg horizon of arable land using heavy machinery.

Difference between arable land and grassland were statistically most significant in the deepest Btg horizon (absence of root and fauna activity), then in surface A horizon (decrease in root, fauna activity and humus content), and the least in subsurface Eg horizon (small changes of porosity due to the absence of the structure).

In agroecological aspect it is important to emphasize that increase of PAW of the surface A horizon of arable and grass land compared to forest was not significant. Significant decrease of S values in A horizon of arable land opposite to forest land and grassland, and grassland opposite to forest land was caused by decrease of total porosity and macro porosity of the soil. All of this was caused by differences in diameter, dispersion, and biomass of root network and fauna activity, and most probably decrease in humus content, as shown in Table 1 and as reported by Dugonjic et al. (2013). 


\section{Conclusions}

Generally, examined Planosols in Mačva and Pocerina had adverse water characteristics due to soil genesis, i.e. soil texture. Through the whole soil profile (A - Eg - Btg horizons) of arable and grass land compared to forest land there was a reduction of $S$ and increase of FC, LCP and PWP values $(p<0.01)$. Saturated hydraulic conductivity was significantly lower in arable land compared to forest land $(p<0.05)$. These changes came from decrease of total porosity and pore size distribution (decrease of macro porosity and increase of micro porosity) probably because of humus content decrease, presence and characteristics of root and fauna activity.

Impact of humus on total porosity, macro porosity and $\mathrm{S}$ was shown in high correlation values between these parameters. Decrease of macro porosity has adverse effect because it implies lower air capacity of A horizon of arable and grassland, i.e. weaker aeration of the soil. Decrease of $\mathrm{S}$ and macro porosity is particularly unfavourable in Planosols, which in wet period of the year suffer from stagnating water and oxygen deficiency. Results of our research showed that the risk of oxygen deficiency can be expressed in the following order: arable land $>$ grass land $>$ forest land (as the depth of $A$, Eg and Btg horizon did not differ significantly).

\section{References}

Caravaca, F., Barea, J.M., Figueroa, D., \& Roldán, A. (2002). Assessing the effectiveness of mycorrhizal inoculation and soil compost addition for enhancing reafforestation with Olea europaea subsp. sylvestris through changes in soil biological and physical parameters. Appl Soil Ecol., 20(2), 107-118. doi:10.1016/ s0929-1393(02)00015-x

Dugonjić, M., Cupac, S., Djordjević, A., Vicentijević, M., Knežević, M., \& Tomić, Z. (2013). Sadržaj i grupno-frakcioni sastav humusa u ravničarskom i obronačnom pseudogleju južne Mačve i Pocerine. Glasnik Šumarskog fakulteta, 107, 71-86.

Dugonjić, M., Cupac, S., Tomić, Z., Bacanović, D., \& Djordjević, A. (2011). Soil texture of Psudogley soils on plains and slopes of southern Mačva and Pocerina under forest, grassland and arable land. Zemlište i biljkea, 60(3), 117-125.

Giertz, S., Junge, B., \& Diekkrüger, B. (2005). Assessing the effects of land use change on soil physical properties and hydrological processes in the sub-humid tropical environment of West Africa. Phys Chem Earth, 30(8-10), 485-496. doi:10.1016/ j.pce.2005.07.003

Harden, C.P. (2006). Human impacts on headwater fluvial systems in the northern and central Andes. Geomorphology, 79(3-4), 249-263. doi:10.1016/j.geomorph.2006.06.021

IUSS Working Group WRB. (2006). World reference base for soil resources. World Soil Resources Reports. Rome: FAO.

Lee, K.E., \& Foster, R.C. (1991). Soil fauna and soil structure. Aust J Soil Res, 29(6), 745-775. doi:10.1071/SR9910745

Marzaioli, R., D’Ascoli, R., de Pascale, R.A., \& Rutigliano, F.A. (2010). Soil quality in a Mediterranean area of Southern Italy as related to different land use types. Appl Soil Ecol., 44(3), 205-212. doi:10.1016/j.apsoil.2009.12.007

O'Geen, A.T. (2012). Soil Water Dynamics. Nature Education Knowledge, 3(6), 12

Price, K., Jackson, C.R., \& Parker, A.J. (2010). Variation of surficial soil hydraulic properties across land uses in the southern Blue Ridge Mountains, North Carolina, USA. J Hydrol, 383(3-4), 256268. doi:10.1016/j.jhydrol.2009.12.041

Rasiah, V., \& Kay, B.D. (1995). Runoff and soil loss as influenced by selected stability parameters and cropping and tillage practices. Geoderma, 68(4), 321-329. doi:10.1016/0016-7061(95)00043-7

Reiners, W.A., Bouwman, A.F., Parsons, W.F.J., \& Keller, M. (1994). Tropical Rain Forest Conversion to Pasture: Changes in Vegetation and Soil Properties. Ecol Appl , 4(2), 363-377. doi: $10.2307 / 1941940$

Sánchez-Marañón, M., Soriano, M., Delgado, G., \& Delgado, R. (2002). Soil Quality in Mediterranean Mountain Environments. Soil Sci Soc Am J., 66(3), 948-958. doi:10.2136/sssaj2002.0948

Schwartz, R.C., Evett, S.R., \& Unger, P.W. (2003). Soil hydraulic properties of cropland compared with reestablished and native grassland. Geoderma, 116(1-2), 47-60. doi:10.1016/s0016-7061(03)00093-4

Škorić, A., Filipovski, G., \& Ćirić, M. (1985). Klasifikacija zemliišta Jugoslavije. Sarajevo: Akademija nauke i umetnosti Bosne i Hercegovine.

Tanasijević, Dj., \& Pavićević, N. (1953). Pedološki pokrivač Mačve, Pocerine i Jadra. Zemlisste i biljka, 2.

Tanasijević, D., Antonović, G., Aleksić, Z., Pavićević, N., Filipović, D., \& Spasojević, M. (1966). Pedološki pokrivač zapadne $i$ severozapadne Srbije. Beograd: Institut za proučavanje zemljišta u Topčideru.

van Reeuwijk, L.P. (2002). Procedures for soil analysis. Wageningen: ISRIC, FAO.

\section{Uticaj načina korišćenja na vodne karakteristike planosola (Južna Mačva i Pocerina, Srbija)}

\section{Mladen Dugonjić · Svjetlana Radmanović · Aleksandar Đorđević · Zorica Tomić · Nataša Nikolić $\cdot$ Ljiljana Tanasić}

Sažetak: Cilj rada je utvrđivanje promena u vodnim kapacitetima i vodopropusnosti planosola na području Mačve i Pocerine zbog pretvaranja šuma u travnjake i njive. Promena načina korišćenja značajno je uticala na vodne kapacitete, ali ne i na vodopropusnost. Generalno u poređenju sa šumama, u njivama i travnjacima je došlo do smanjenja MVK i povećanja vrednosti PVK, LVK i VV. Navedene promene su posledica smanjenja ukupne poroznosti i promene diferencijalne poroznosti. Promene u njivama i travnjacima su najznačajnije u Btg horizontu (odustvo korenovog sistema i faune), zatim u A horizontu (smanjenje korenovog sistema, aktivnosti faune i sadržaja humusa), a najmanje u Eg horizontu (manja promena poroznosti zbog nestrukturnosti). Sa agroekološkog aspekta je važno istaći da u A horizontu njiva i travnjaka u poređenju sa šumama povećanje KPV i smanjenje SHC nije značajno; značajno smanjenje MVK i makroporoznosti povećava rizik od nedostatka kiseonika u vlažnom delu godine ovim redom: njive $>$ travnjaci $>$ šume.

Ključne reči: njiva, planosol, propusnost za vodu, šuma, travnjak, vodni kapacitet 